\title{
Evaluation of Antagonistic Potential of Bacillus spp. and Trichoderma spp. against Sclerotium rolfsii Sacc. causing Collar Rot Disease in Solanum melongena $\mathrm{L}$.
}

\author{
A. Abinaya ${ }^{1}$, K. Kalpana ${ }^{*}$, E.G. Ebenezar ${ }^{2}$, S. Thiruvudainambi ${ }^{1}$, \\ M. Theradimani ${ }^{1}$ and R. Arunkumar ${ }^{3}$
}

${ }^{1}$ Department of Plant Pathology, Agricultural College and Research Institute, Tamil Nadu Agricultural University, Madurai, Tamil Nadu, India

${ }^{2}$ Department of Plant Pathology, Agricultural College and Research Institute, Tamil Nadu Agricultural University, Killikulam, Tamil Nadu, India

${ }^{3}$ Department of Horticulture, Krishi Vigyan Kendra, Agricultural College and Research Institute, Tamil Nadu Agricultural University, Madurai, Tamil Nadu, India

*Corresponding author

\section{A B S T R A C T}

Keywords

Solanum melongena, collar rot, Sclerotium rolfsii, Bacillus spp., Trichoderma spp., Dual culture technique

Article Info

Accepted: 07 November 2020 Available Online: 10 December 2020
Collar rot caused by Sclerotium rolfsii Sacc. is one of the catastrophic diseases of brinjal causing in negligible yield loss globally. The present study investigated the effect of Bacillus spp. and Trichoderma spp. on the growth of collar rot pathogen $S$. rolfsii under in vitro. The highest disease incidence was noticed in Vilangudi village which recorded $42.4 \%$ followed by Thirumangalam village $(39.5 \%)$ and least incidence was noticed in Kottampatty village $(8.8 \%)$ of Madurai district in Tamil Nadu. Results showed that the mycelial growth of the $S$. rolfsii was significantly inhibited by the Trichoderma isolate T-AG with 84.44 per cent growth reduction followed by the Bacillus isolate B-VI with 55.55 per cent growth reduction.

\section{Introduction}

Brinjal (Solanum melongena L.) shares many other names such as eggplant/aubergine and belongs to the Solanaceae family. It is originated in the Indian subcontinent and China as reported by (Martin and Rhodes,
1979). It is one of the principal renowned crops acclimatizing tropics and subtropics. It fits into distinct agro climatic zones all-round the year proving its versatility (Singh et al., 2014).India is recorded with the production of 12,779.54 thousand tonnes of Brinjal. Correspondingly, Tamil Nadu occupies 
eleventh place with regard to production of brinjal in India (Apeda, 2017-18). Brinjal is cultivated under an area of 728.00 thousand hectares resulting for an yearly yield of $12,660.00$ thousand metric tonnes and productivity of 17.7 metric tonnes per hectare (Indiastat, 2018-19). Brinjal extracts have been reported to victoriously quash the growth and development of tumours, lung cancer (Matsubara et al., 2005), inhibit inflammation (Keli et al., 1996) and cardiovascular diseases (Knekt et al., 1996; Knekt et al., 1997). Being a nutrient dense food, it can provide at least $5 \%$ of a person's routine requirement of fiber, flavonoids, copper, vitamin B-6 and thiamine. Extracts of the purple skinned brinjal has been shown to exhibit a lofty ability in scavenging superoxide radicals and inhibition of hydroxyl radical production by chelating ferrous iron (Kaneyuki et al., 1999; Noda et al., 2000). All in all, brinjal has received a skyrocketing zest among consumers and researchers throughout and is ranked among top 10 vegetables with regard to antioxidant capacity (Cao et al., 1996). It is decimated by multiple pathogens categorized into fungi, bacteria and viruses. Among fungal diseases, collar rot caused by SclerotiumrolfsiiSacc.is turning out be a profuse menace under nursery and field cultivated brinjal crop. It can infect seeds, seedlings and mature plants in the field, cause diseases to fresh vegetables and rhizomes, while in storage and transit. Collar rot may cause up to $30-50 \%$ loss in fruit yield in eggplant (Siddique et al., 2016). The pathogen invades the collar zone of the host adjacent to the soil level causing death by disrupting translocation of food from top to root zone (Begum et al., 1985). Itis a facultative saprophyte and can maintain its generation even under drastic set up by formation of sclerotia. So, it is ineffective and uneconomical to control the pathogen with chemical, which being soil-borne and omnivorous. Hence, biological control which comprises the employment of various microorganisms to control plant pathogens is seemed to be very beneficial as it may be economically as well as environmentally useful and safer option for modern agriculture practice today. Suryawanshi et al., (2015) reported that Bacillus megaterium exhibited the highest mycelial growth inhibition $(87.85 \%)$ against S.rolfsii. Doley and Jite, (2012) reported that the Trichoderma isolate inhibited the radial growth of $S$. rolfsiiby 75\%. Henis et al., (1982) reported mycoparasitism (penetration and infection) of Trichoderma spp. against S.rolfsii. Jadon and Tiwari, (2011) showed that $T$. viridewas found most effective in inhibiting both mycelial growth $(81.2 \%)$ and sclerotia production(14.15) of $S$. rolfsii. So keeping this in view, the present study was carried out to study the effect of fungal and bacterial biocontrol agents against the deadly pathogen $S$. rolfsii causing collar rot disease in brinjal.

\section{Materials and Methods}

\section{Collection and isolation of Sclerotiumrolfsii Sacc.}

A survey was conducted in prominent brinjal growing districts of Tamil Nadu. The plants exhibiting collar rot including sclerotial germination which may measure $1-3 \mathrm{~mm}$ with mustard like appearance upon surfaces of the infected plant parts were collected (Koike, 2004). Then the pathogen was isolated through tissue segment method where the infected tissues along with adjacent small unaffected tissues were cut into small pieces, surface sterilized and plated on potato dextrose agar medium. The infected portion along with healthy portion of plant was cut into small pieces and surface sterilized with $1 \%$ Sodium hypochlorite for 1 minute, washed shortly in sterile distilled water and dried on sterile filter paper. The dried pieces were plated onto sterile Petri plate containing 
PDA (potato dextrose agar) medium and incubated at $25 \pm 1^{\circ} \mathrm{C}$ for seven days. Pure culture of the pathogen was acquired following hyphal tip method and subsequently multiplied on PDA medium in test tubes and Petri dishes and stored at $4^{\circ} \mathrm{C}$ for further studies (Mian, 1995).

\section{Assessing the virulence of the pathogen}

The ten purified isolates of S.rolfsii were tested for pathogenicity under in vivo. The isolates were mass multiplied in sand maize medium. Sand and ground maize seeds were mixed in the ratio of $19: 1$, moistened to 50 per cent moisture content and filled in polythene bags. These bags were autoclaved at $1.4 \mathrm{~kg} / \mathrm{cm}^{2}$ pressure for 20 minutes. Then seven days old actively growing mycelial discs $(6 \mathrm{~mm})$ of the pathogen isolate was inoculated into each bag under aseptic condition and incubated at room temperature $\left(28 \pm 2^{\circ} \mathrm{C}\right)$ for 10 days. Then thirty days old brinjal seedlings were transplanted to the pot containing sand maize medium mass multiplied with $S$. rolfsii. Symptoms expression was observed five days after inoculation and percent disease incidence was derived.

Percent Disease Incidence $=\left(\frac{\text { Number of plants rotted }}{\text { Total memberofplants obsereved }} \times 100\right)$

\section{Isolation of Bacillus spp.}

The soil samples were collected from rhizosphere region of brinjal crop at various districts of Tamil Nadu. Plant roots adhered with soil was taken for isolation. Before isolation, the roots were gently shaken to remove excess soil and vortexed for $10 \mathrm{~min}$ in sterile distilled water $(1 \mathrm{~g}$ per $10 \mathrm{ml})$. Samples were serially diluted with sterile distilled water from $10^{-1}$ to $10^{-6}$ dilutions and one $\mathrm{ml}$ of the aliquot from $10^{-5}$ and $10^{-6}$ dilutions were plated onto nutrient agar medium(Roy et al.,
2007). The isolates were characterised morphologically and biochemically by following Bergey's Manual of Systematic Bacteriology. Then these Isolates were maintained on nutrient agar medium at $4^{\circ} \mathrm{C}$ for progressive study ahead.

\section{Isolation of Trichoderma spp.}

The soil samples were collected from the root zones of brinjal crop at different locations in Tamil Nadu. Before isolation, the roots were gently shaken to remove excess soil and vortexed for $10 \mathrm{~min}$ in sterile distilled water $(1 \mathrm{~g}$ per $10 \mathrm{ml})$. Samples were serially diluted with sterile distilled water from $10^{-1}$ to $10^{-4}$ dilutions and $1 \mathrm{ml}$ of the aliquot from $10^{-3}$ and $10^{-4}$ dilutions were plated on Trichoderma selective medium.The Petri dishes were rotated clockwise and anticlockwise for uniform distribution and incubated for five days at room temperature $\left(25 \pm 3^{\circ} \mathrm{C}\right)$. Colonies of Trichoderma isolates were identified following a standard key. Then isolates of Trichoderma were purified on PDA plates following single hyphal tip technique. After purification, all of the isolates were preserved on PDA slants at $4^{\circ} \mathrm{C}$ as stock culture for successive use.

In vitro screening of different isolates of Bacillus spp. against the mycelial growth of S.rolfsii

Eleven isolates of Bacillus spp. were screened against the virulent isolate of S.rolfsii IS(VIL)-9under in vitro by adapting dual culture technique (Dennis and Webster, 1971). Each bacterial isolate was streaked at one side of the Petri dish containing PDA at one $\mathrm{cm}$ away from the periphery of the Petri dish. A nine mm mycelial disc of S.rolfsii was placed at a contrary side of the Petri dish at one $\mathrm{cm}$ away from the periphery of the Petri dish and perpendicular to the bacterial streak. Control plates were maintained without 
bacterial streak. Three replications were maintained at room temperature for four days. After attaining complete growth of the pathogen in the control plate, percent inhibition over control was calculated using the formula proposed by (Pandey and Upadhyay, 2000).

$$
\mathrm{PI}={ }^{*} \begin{gathered}
\mathrm{D}_{\mathrm{c}}-\mathrm{D}_{\mathrm{t}} \\
100 \\
\mathrm{D}_{\mathrm{c}}
\end{gathered}
$$

$\mathrm{D}_{\mathrm{c}}$ =average diameter of fungal growth $(\mathrm{cm})$ in control

$\mathrm{D}_{\mathrm{t}}=$ average diameter of fungal growth $(\mathrm{cm})$ in treatment

In vitro screening of different isolates of Trichoderma spp. against the mycelial growth of S.rolfsii

Twelve isolates of Trichoderma spp were evaluated in in vitro against $S$. rolfsii, applying dual culture technique (Dennis and Webster, 1971). Seven days old cultures of Trichoderma spp. and pathogen ( $S$. rolfsii) were used for the study. The culture discs ( 9 $\mathrm{mm}$ dia.) of the test pathogen and bioagent were cut out with sterilized cork borer. Then two culture discs, one each of the test pathogen and bioagent were placed aseptically at equidistance and exactly opposite to each other on solidified PDA medium in Petri plates and plates were incubated at $28 \pm 2{ }^{\circ} \mathrm{C}$. Three replication were maintained. The PDA plate inoculated only with culture disc of test pathogen was maintained as control.

$$
\begin{gathered}
D_{\mathrm{c}}-\mathrm{D}_{\mathrm{t}} \\
\mathbf{P I}=* 100 \\
\mathrm{D}_{\mathrm{c}}
\end{gathered}
$$

$\mathrm{D}_{\mathrm{c}}$ =average diameter of fungal growth $(\mathrm{cm})$ in control

$\mathrm{D}_{\mathrm{t}}=$ average diameter of fungal growth $(\mathrm{cm})$ in treatment

\section{Statistical analysis}

Experimental data were statistically analyzed using analysis of variance (ANOVA) and the Statistical Package for the Social Sciences version 16.0. The treatment means were separated at 5\% significant level using Duncan's Multiple Range Test (DMRT).

\section{Results and Discussion}

\section{Collection and isolation of the pathogen}

The data obtained during the survey conducted in major brinjal growing areas of Tamil Nadu was presented in the table 1. Isolates of S.rolfsii were isolated from diseased plants showing the typical symptoms of collar rot and presence of sclerotia on the root surface using PDA medium. The fungi were observed under microscope, identified as S.rolfsii based on the morphological characters of the fungus and sclerotial structures. The isolated fungus produced dark, white coloured fluffy mycelium and brown sclerotia on the PDA medium. Similarly, Morton, (1969) observed that growth and branching of $S$. rolfsii filamentous fungi occurred at the apex of mycelium and pointed out that growth was regulated by a delicate balance between cell wall synthesis and degradation. Zarani and Christias, (1997); Sarma et al., (2002) reported the production of small, spherical, tan to dark brown and black colored sclerotia in the Petri plates. Thus, the purified fungal culture was sent to the Indian Type Culture Collection, PUSA, IARI, and was confirmed as Sclerotium rolfsii with the I.D.No 11,305.20.

\section{Assessing the virulence of the pathogen}

The isolated pathogen was proved to be pathogenic on brinjal plants. Inoculated plants produced rotting and disruption in translocating the food from top to root zone 
with sclerotia on the root surface. No such symptoms were observed on the uninoculated control plants. Among the different isolates tested, the isolate from Vilangudi was found to be most virulent in inducing the collar rot symptoms. Similarly, Bhuiyan et al., (2012) tested 10 isolates of $S$. rolfsii for their ability to cause foot and root rot disease of soybean by soil infestation method in pot culture experiment under shade condition. Then the causal agent of pre-emergent seedling mortality was confirmed after re-isolation of the pathogen from un-germinated seeds, infected root and stems.

Table.1 Survey for assessing the collar rot disease incidence in brinjal in different location of Tamil Nadu

\begin{tabular}{|c|c|c|c|c|c|c|}
\hline \multirow[t]{2}{*}{ S. No } & \multirow[t]{2}{*}{ Place of collection } & \multirow[t]{2}{*}{ Districts } & \multirow[t]{2}{*}{ Isolate code } & \multicolumn{2}{|c|}{ Geo co ordinates } & \multirow{2}{*}{$\begin{array}{c}\text { Percent } \\
\text { Disease } \\
\text { Incidence }(\%)\end{array}$} \\
\hline & & & & Latitude & Longitude & \\
\hline 1 & Thirumangalam & Madurai & IS (THI)-1 & $9.8216^{\circ} \mathrm{N}$ & $77.9891^{\circ} \mathrm{E}$ & 39.5 \\
\hline 2 & Kanakiliyanallur & Trichy & IS (KAN)-2 & $10.9956^{\circ} \mathrm{N}$ & $78.8800^{\circ} \mathrm{E}$ & 18.8 \\
\hline 3 & AC \& RI & Madurai & IS (AGR)-3 & $9.9699^{\circ} \mathrm{N}$ & $78.2040^{\circ} \mathrm{E}$ & 10.2 \\
\hline 4 & Palamedu & Madurai & IS (PAL)-4 & $10.1043^{\circ} \mathrm{N}$ & $78.1130^{\circ} \mathrm{E}$ & 35.2 \\
\hline 5 & Vandalaikudalur & Trichy & IS (VAN)-5 & $10.9701 \mathrm{~N}$ & $78.8878 \mathrm{E}$ & 12.5 \\
\hline 6 & K.K.Patty & Theni & IS (KKP)-6 & $9.7386^{\circ} \mathrm{N}$ & $77.3181^{\circ} \mathrm{E}$ & 15.8 \\
\hline 7 & Pudhupatty & Theni & IS (PUD)-7 & $9.4356^{\circ} \mathrm{N}$ & $77.9996^{\circ} \mathrm{E}$ & 21.5 \\
\hline 8 & Ayanpannapatty & Trichy & IS (AYA)-8 & $9.6313^{\circ} \mathrm{N}$ & $77.7666^{\circ} \mathrm{E}$ & 24.6 \\
\hline 9 & Vilangudi & Madurai & IS (VIL)-9 & $9.9498^{\circ} \mathrm{N}$ & $78.0879^{\circ} \mathrm{E}$ & 42.4 \\
\hline 10 & Kottampatty & Trichy & IS (KOT)-10 & $10.6228^{\circ} \mathrm{N}$ & $78.4471^{\circ} \mathrm{E}$ & 8.8 \\
\hline
\end{tabular}

Table.2 Bacillus spp. isolated from rhizosphere region of brinjal plant in different locations in Tamil Nadu

\begin{tabular}{|l|l|l|l|l|l|l|}
\hline S. & Place & Districts & Isolate & \multicolumn{2}{l|}{ Geo co ordinates } & Colony characters \\
\cline { 5 - 6 } No & collection & Latitude & Longitude & \\
\hline $\mathbf{1}$ & Thirumangalam & Madurai & B-TH & $9.8216^{\circ} \mathrm{N}$ & $77.9891^{\circ} \mathrm{E}$ & Dull white colonies \\
\hline $\mathbf{2}$ & Kanakiliyanallur & Trichy & B-KA & $10.9956^{\circ} \mathrm{N}$ & $78.8800^{\circ} \mathrm{E}$ & Regular white colonies \\
\hline $\mathbf{3}$ & AC \& RI & Madurai & B-AG & $9.9699^{\circ} \mathrm{N}$ & $78.2040^{\circ} \mathrm{E}$ & Bright white colonies \\
\hline $\mathbf{4}$ & Palamedu & Madurai & B-PA & $10.1043^{\circ} \mathrm{N}$ & $78.1130^{\circ} \mathrm{E}$ & Irregular creamy colonies \\
\hline $\mathbf{5}$ & Vandalaikudalur & Trichy & B-VA & $10.9701^{\circ} \mathrm{N}$ & $78.8878 \mathrm{E}$ & Thin white colonies \\
\hline $\mathbf{6}$ & K.K.Patty & Theni & B-KK & $9.7386^{\circ} \mathrm{N}$ & $77.3181^{\circ} \mathrm{E}$ & $\begin{array}{l}\text { Regular bright } \\
\text { colonies }\end{array}$ \\
\hline $\mathbf{7}$ & Pudhupatty & Theni & B-PU & $9.4356^{\circ} \mathrm{N}$ & $77.9996^{\circ} \mathrm{E}$ & $\begin{array}{l}\text { Irregular dull } \\
\text { colonies }\end{array}$ \\
\hline $\mathbf{8}$ & Ayanpannapatty & Trichy & B-AY & $9.6313^{\circ} \mathrm{N}$ & $77.7666^{\circ} \mathrm{E}$ & Light yellow colonies \\
\hline $\mathbf{9}$ & Vilangudi & Madurai & B-VI & $9.9498^{\circ} \mathrm{N}$ & $78.0879^{\circ} \mathrm{E}$ & Flat bright white colonies \\
\hline $\mathbf{1 0}$ & Kottapatty & Trichy & B-KO & $10.6228^{\circ} \mathrm{N}$ & $78.4471^{\circ} \mathrm{E}$ & Creamy white colonies \\
\hline $\mathbf{1 1}$ & CR Palayam & Trichy & B-CR & $11.2000^{\circ} \mathrm{N}$ & $78.4900^{\circ} \mathrm{E}$ & Bright white colonies \\
\hline
\end{tabular}


Table.3 Trichoderma spp. isolated from rhizosphere region of brinjal plant indifferent locations of Tamil Nadu

\begin{tabular}{|c|c|c|c|c|c|c|}
\hline \multirow{2}{*}{$\begin{array}{l}\text { S. } \\
\text { No }\end{array}$} & \multirow[t]{2}{*}{ Place of collection } & \multirow[t]{2}{*}{ Districts } & \multirow{2}{*}{$\begin{array}{l}\text { Isolate } \\
\text { code }\end{array}$} & \multicolumn{2}{|c|}{ Geo co ordinates } & \multirow[t]{2}{*}{ Culture characters } \\
\hline & & & & Latitude & Longitude & \\
\hline 1 & Thirumangalam & Madurai & T-TH & $9.8216^{\circ} \mathrm{N}$ & $77.9891^{\circ} \mathrm{E}$ & Scattered in dull green \\
\hline 2 & Kanakiliyanallur & Trichy & T-KA & $10.9956^{\circ} \mathrm{N}$ & $78.8800^{\circ} \mathrm{E}$ & Dull white to dark green \\
\hline 3 & AC \& RI & Madurai & $\mathrm{T}-\mathrm{AG}$ & $9.9699^{\circ} \mathrm{N}$ & $78.2040^{\circ} \mathrm{E}$ & $\begin{array}{l}\text { Tufts of white mycelium } \\
\text { tuning green }\end{array}$ \\
\hline 4 & Palamedu & Madurai & T-PA & $10.1043^{\circ} \mathrm{N}$ & $78.1130^{\circ} \mathrm{E}$ & Yellowish green tufts \\
\hline 5 & Vandalaikudalur & Trichy & $\mathrm{T}-\mathrm{VA}$ & $10.9701 \mathrm{~N}$ & $78.8878 \mathrm{E}$ & $\begin{array}{l}\text { White tufts of mycelium } \\
\text { turning into dark green }\end{array}$ \\
\hline 6 & K.K.Patty & Theni & $\mathrm{T}-\mathrm{KK}$ & $9.7386^{\circ} \mathrm{N}$ & $77.3181^{\circ} \mathrm{E}$ & $\begin{array}{l}\text { White tufts of mycelium } \\
\text { becoming green from the } \\
\text { centre }\end{array}$ \\
\hline 7 & Pudhupatty & Theni & T-PU & $9.4356^{\circ} \mathrm{N}$ & $77.9996^{\circ} \mathrm{E}$ & $\begin{array}{l}\text { Dark green in concentric } \\
\text { rings }\end{array}$ \\
\hline 8 & Ayanpannapatty & Trichy & T-AY & $9.6313^{\circ} \mathrm{N}$ & $77.7666^{\circ} \mathrm{E}$ & $\begin{array}{l}\text { Scattered in minute tufts dark } \\
\text { green }\end{array}$ \\
\hline 9 & Vilangudi & Madurai & T-VI & $9.9498^{\circ} \mathrm{N}$ & $78.0879^{\circ} \mathrm{E}$ & Complete dark green \\
\hline 10 & Kottapatty & Trichy & $\mathrm{T}-\mathrm{KO}$ & $10.6228^{\circ} \mathrm{N}$ & $78.4471^{\circ} \mathrm{E}$ & $\begin{array}{l}\text { White tufts of mycelium } \\
\text { gradually turning into } \\
\text { yellowish green }\end{array}$ \\
\hline 11 & CR Palayam & Trichy & $\mathrm{T}-\mathrm{CR}$ & $11.2000^{\circ} \mathrm{N}$ & $78.4900^{\circ} \mathrm{E}$ & Yellowish green \\
\hline Ck & TNAU & T.V.1 (Che & & $11.0152^{\circ} \mathrm{N}$ & $76.9326^{\circ} \mathrm{E}$ & $\begin{array}{l}\text { White mycelium turning into } \\
\text { Yellowish green }\end{array}$ \\
\hline
\end{tabular}

Table.4 Efficacy of Bacillus spp. against the mycelial growth of S. rolfsii IS (VIL)-9 in in vitro

\begin{tabular}{|l|c|c|c|}
\hline S.No. & Treatments & $\begin{array}{c}\text { Mycelial } \\
\text { growth(cm) }\end{array}$ & $\begin{array}{c}\text { Percent inhibition over } \\
\text { control }\end{array}$ \\
\hline $\mathbf{1}$ & B-TH & 6.20 & 31.11 \\
\hline $\mathbf{2}$ & B-KA & 6.90 & 23.33 \\
\hline $\mathbf{3}$ & B-AG & 6.40 & 28.88 \\
\hline $\mathbf{4}$ & B-PA & 5.90 & 34.44 \\
\hline $\mathbf{5}$ & B-VA & 5.90 & 34.44 \\
\hline $\mathbf{6}$ & B-KK & 6.60 & 26.66 \\
\hline $\mathbf{7}$ & B-PU & 6.40 & 28.88 \\
\hline $\mathbf{8}$ & B-AY & 5.50 & 38.88 \\
\hline $\mathbf{9}$ & B-VI & 4.00 & 55.55 \\
\hline $\mathbf{1 0}$ & B-KO & 4.70 & 47.77 \\
\hline $\mathbf{1 1}$ & B-CR & 5.80 & 35.55 \\
\hline Control & & 9.00 & \\
\hline CD(.05) & & & \\
\hline
\end{tabular}

*Mean of three replications 
Table.5 Efficacy of Trichoderma spp isolates against the mycelial growth of S.rolfsii IS(VIL)-9 in in vitro

\begin{tabular}{|l|c|c|c|}
\hline S.No & Treatments & Mycelial growth(cm) & $\begin{array}{c}\text { Percent inhibition } \\
\text { over control }\end{array}$ \\
\hline $\mathbf{1}$ & T-TH & 5.00 & 44.44 \\
\hline $\mathbf{2}$ & T-KA & 3.70 & 58.88 \\
\hline $\mathbf{3}$ & T-AG & 1.40 & 84.44 \\
\hline $\mathbf{4}$ & T-PA & 4.40 & 51.11 \\
\hline $\mathbf{5}$ & T-VA & 2.60 & 71.11 \\
\hline $\mathbf{6}$ & T-KK & 4.10 & 54.44 \\
\hline $\mathbf{7}$ & T-PU & 4.20 & 53.33 \\
\hline $\mathbf{8}$ & T-AY & 6.10 & 32.22 \\
\hline $\mathbf{9}$ & T-VI & 4.20 & 53.33 \\
\hline $\mathbf{1 0}$ & T-KO & 5.10 & 43.33 \\
\hline $\mathbf{1 1}$ & T-CR & 5.20 & 42.22 \\
\hline $\mathbf{C k}$ & TNAUT.V.1 & 4.10 & 54.44 \\
\hline Control & (Check) & & \\
\hline CD(.05) & & 9.00 & \\
\hline
\end{tabular}

Smith et al., (1986) proved that S. rolfsii isolate from sorghum was found to be pathogenic on greenhouse grown host plants like bean, sugar beet and carrot. Sultana et al., (2012) evaluated $S$. rolfsii for its pathogenicity in a pot culture experiment under the shady atmosphere by soil and seed infestation. Expression of pre-emergence and post-emergence seedling mortality were observed and recorded frequently after sowing. Re-isolation of the pathogen was done to confirm the causal agent of seedling infection as $S$. rolfsii

\section{Isolation and confirmation of biocontrol agents}

Eleven isolates of Bacillus spp. and twelve isolates of Trichoderma spp. were isolated from the rhizosphere region of brinjal plant collected at various places in Tamil Nadu. They were assigned different names as per the biochemical analysis results which confirmed the fungal isolates as Trichoderma spp. and bacterial isolates as Bacillus spp. Similarly, Bacillus spp. were identified based upon their colony characters, microscopic characteristics and biochemical characters viz., starch hydrolysis (Iverson and Millis, 1974), catalase test (Schaad, 1992) and oxidase test (Gordon and McLeod, 1928). Trichoderma spp. were identified based on the morphological features like colony colour, concentric rings with green conidial production, irregular yellow zone without conidia and white pustules on the green mat of conidia depending upon species. Trichoderma spp. isolates were identified based on mycological characters.

Effect of antagonistic activity of Bacillus spp. against $S$. rolfsii under in vitro

Eleven isolates of Bacillus spp. were tested against $S$. rolfsii under in vitro. Among the isolates, the isolate B-VIdraconianly inhibited the mycelial growth of $S$. rolfsii $(4.0 \mathrm{~cm})$ with 
55.55 per cent growth reduction followed by $\mathrm{B}-\mathrm{KO}$ and B-AY which were succeedingly effective and recorded 4.7 and $5.5 \mathrm{~cm}$ growth of the pathogen with 47.77 and 38.88per cent growth reduction over control respectively. Similarly, Suryawanshi et al., (2015) reported that $B$. Subtilis and B. megaterium were fungistatic against $S$. rolfsii. Suneeta et al., (2017) reported that $B$. subtilis was expressed to be significantly different between antagonistic Bacillus strains which proliferated the yield and cut down the collar rot incidence $(44.21 \%)$ over the control of gerbera collar rot. De Curtis et al., (2010) reported that $B$. cepacia significantly inhibited damping-off caused by $S$. rolfsii, reducing the disease index by $81 \%$ compared to the untreated control. Shifa et al., (2015) tested that $B$. subtilis strain G-1 was the most effective in inhibiting the mycelial growth of S.rolfsii and recorded an inhibition of $28 \%$. B. subtilis secreted antifungal substance which is highly antagonistic against $S$. rolfsii (Nalisha et al., 2006). Gholami et al., (2014) reported that the Bacillus sp. and S. cyaneofuscatus isolates showed the same capacity for reducing the disease severity of $S$. rolfsii for over $50 \%$ (Table $2-4$ ).

Effect of antagonistic activity of Trichoderma spp. against $S$. rolfsii under in vitro

Twelve isolates of Trichoderma spp. and check (TNAU T.v. 1) were tested against $S$. rolfsii under in vitro and tabulated in the table 5. Among the isolates, T-AG drastically inhibited the mycelial growth of $S$. rolfsii $(1.40 \mathrm{~cm})$ with 84.44 per cent growth reduction followed by T-VA and T-KA which were rigorously effective and recorded 2.60 and $3.70 \mathrm{~cm}$ growth of the pathogen with 71.11 and 58.88 per cent growth reduction over control respectively. Similarly, Doley and Jite, (2012) observed that the bioagent $T$. Viride inhibited $75 \%$ of $S$. rolfsii growth.
Bhuiyan et al., (2012) showed $83.06 \%$ significant reduction of mycelial growth of $S$. rolfsiiin presence of Trichoderma spp. Madhavi and Bhattiprolu (2011) reported the highest $(57.5 \%)$ mycelial inhibition of $S$. rolfsiiwith $T$. harzianum resulting similar to Virupaksha Prabhu et al., (1997) who worked with T. Harzianum against collar rot of cotton. Singh and Singh, (1994) proved that $T$. harzianum showed highest antagonistic activity (73\%) against $S$. rolfsii of brinjal.

In conclusion there are umpteen results available for the control of $S$. rolfsii under in vitro by bioagents like Bacillus spp. and Trichoderma spp. Present study revealed that the bioagents expressed antifungal activity through competition, antibiosis, mycoparasitism and induced systemic resistance. Moreover, the lofty cost connected with the use of chemical fungicides to control soil borne pathogenic fungi is an extensive limiting factor restraining the profitability of crop production. The use of bioagents in lieu of fungicides or bactericides with high potential is the need of the hour to protect the crop with no harm to environment

\section{References}

Begum, S., B. Choudhury, and H. Ahmed. 1985. "Screening of brinjal varieties for resistance to Sclerotium rolfsii." 1. National Plant Pathology Conference. Joydebpur (Bangladesh). 13-14 Apr 1985.

Bhuiyan, M., M. Rahman, and K. Bhuiyan. 2012. "In vitro screening of fungicides and antagonists against Sclerotium rolfsii." African journal of Biotechnology 11 (82): 14822-14827.

Cao, G., E. Sofic, and R.L. Prior. 1996. "Antioxidant capacity of tea and common vegetables." Journal of agricultural and food chemistry 44 (11): 3426-3431.

De Curtis, F., G. Lima, D. Vitullo, and V. De 
Cicco. 2010. "Biocontrol of Rhizoctonia solani and Sclerotium rolfsii on tomato by delivering antagonistic bacteria through a drip irrigation system." Crop Protection 29 (7): 663-670.

Dennis, C., and J. Webster. 1971. "Antagonistic properties of species-groups of Trichoderma: III. Hyphal interaction." Transactions of the British Mycological Society 57 (3): 363-IN362.

Doley, K., and P.K. Jite. 2012. "In-vitro efficacy of Trichoderma viride against Sclerotium rolfsii and Macrophomina phaseolina." Notulae Scientia Biologicae 4 (4): 39-44.

Gholami, M., R. Khakvar, and G. Niknam. 2014. "Introduction of some new endophytic bacteria from Bacillus and Streptomyces genera as successful biocontrol agents against Sclerotium rolfsii." Archives of Phytopathology and Plant Protection 47 (1): 122-130.

Gordon, J., and J. McLeod. 1928. "The Practical Application of the Direct Oxidase Reaction hi Bacteriology." Journal of Pathology and Bacteriology 31:185-190.

Henis, Y., P. Adams, G. Papavizas, and J. Lewis. 1982. "Penetration of sclerotia of Sclerotium rolfsii by Trichoderma spp." Phytopathology 72: 70-74.

Iverson, W., and N.F. Millis. 1974. "A method for the detection of starch hydrolysis by bacteria." Journal of Applied Bacteriology 37 (3): 443-446.

Jadon, K.S., and P. Tiwari. 2011. "Pathogen physiology and management of Brinjal collar rot caused by Sclerotium rolfsii." Annals of Plant Protection Sciences 19 (1):113-117.

Kaneyuki, T., Y. Noda, M.G. Traber, A. Mori, and L. Packer. 1999. "Superoxide anion and hydroxyl radical scavenging activities of vegetable extracts measured using electron spin resonance." IUBMB Life 47 (6):979-989.

Keli, S.O., M.G. Hertog, E.J. Feskens, and D. Kromhout. 1996. "Dietary flavonoids, antioxidant vitamins, and incidence of stroke: the Zutphen study." Archives of
Internal medicine 156 (6): 637-642.

Knekt, P., R. Jarvinen, A. Reunanen, and J. Maatela. 1996. "Flavonoid intake and coronary mortality in Finland: a cohort study." Bmj 312 (7029): 478-481.

Knekt, P., R. Järvinen, R. Seppänen, M. Heliövaara, L. Teppo, E. Pukkala, and A. Aromaa. 1997. "Dietary flavonoids and the risk of lung cancer and other malignant neoplasms." American journal of epidemiology 146 (3): 223230.

Koike, S. 2004. "Southern blight of Jerusalem artichoke caused by Sclerotium rolfsii in California." Plant disease 88 (7): 769769.

Madhavi, G.B., and S. Bhattiprolu. 2011. "Integrated disease management of dry root rot of chilli incited by Sclerotium rolfsii (Sacc.)." International Journal of Plant, animal and environmental sciences 1 (2): 31-37.

Martin, F., and A. Rhodes. 1979. "Subspecific grouping of eggplant cultivars." Euphytica 28 (2): 367-383.

Matsubara, K., T. Kaneyuki, T. Miyake, and M. Mori. 2005. "Antiangiogenic activity of nasunin, an antioxidant anthocyanin, in eggplant peels." Journal of agricultural and food chemistry 53 (16): 6272-6275.

Mian, I. 1995. "Methods in plant pathology." IPSA-JICA project publication 24:100.

Morton, A. 1969. "JH Burnett, Fundamentals of Mycology, Edward Arnold (Publishers) Ltd., London (1968), Pp. xiii+ 546. Price: 130s.(paper edition 65s.)." Transactions of the British Mycological Society 52 (3):515.

Nalisha, I., M. Muskhazli, and T. Nor Farizan. 2006. "Production of Bioactive Compounds by Bacillus subtilis against Sclerotium rolfsii." Malaysian Journal of Microbiology 2 (2):19-23.

Noda, Y., T. Kneyuki, K. Igarashi, A. Mori, and L. Packer. 2000. "Antioxidant activity of nasunin, an anthocyanin in eggplant peels." Toxicology 148 (2-3): 119-123.

Pandey, K., and J. Upadhyay. 2000. "Microbial population from rhizosphere and non- 
rhizosphere soil of pigeonpea: screening for resident antagonist and mode of mycoparasitism." Journal of Mycology and Plant Pathology 30 (1): 7-10.

Roy, S., C. Suchismita, and S. Mukherjee. 2007. "Biological control of Phytophthora spp. with a novel indigenous Pseudomonas isolate." Journal of Mycopathological Research 45 (1): 117-121.

Sarma, B., U. Singh, and K. Singh. 2002. "Variability in Indian isolates of Sclerotium rolfsii." Mycologia 94 (6): 1051-1058.

Schaad, N. 1992. "Laboratory guide for identification of plant pathogen bacteria, 2nd edn, 44-58." Lucknow: International Book Distributing Co.

Shifa, H., C. Gopalakrishnan, and R. Velazhahan. 2015. "Efficacy of Bacillus subtilis G-1 in suppression of stem rot caused by Sclerotium rolfsii and growth promotion of groundnut." International Journal of Agriculture, Environment and Biotechnology 8 (1):111-118.

Siddique, M.N.A., A.N.F. Ahmmed, M.G.H. Mazumder, M. Khaiyam, and M.R. Islam. 2016. "Evaluation of some fungicides and bio-agents against Sclerotium rolfsii and foot and root rot disease of eggplant (Solanum melongena L.)." The Agriculturists 14 (1): 92-97.

Singh, A., and D. Singh. 1994. "Bio-control of Sclerotium rolfsii Sacc. causing collar rot of brinjal." Journal of Biological Control 8 (2): 105-110.
Singh, B., S. Singh, and S. Yadav. 2014. "Some important plant pathogenic disease of brinjal (Solanum melongena L.) and their management." Plant Pathology Journal (Faisalabad) 13 (3): 208-213.

Smith, V., Z. Punja, and S. Jenkins. 1986. "A histological study of infection of host tissue by Sclerotium rolfsii." Phytopathology 76 (8): 755-759.

Sultana, J., Z. Pervez, H. Rahman, M. Islam, Z. Pervez, H. Rahman, and M. Islam. 2012. "Integrated approach of mitigating root rot of chilli caused by Sclerotium rolfsii." Bangladesh Research pub. Jr 6 (3):270.

Suneeta, P., K.E.A. Aiyanathan, and S. Nakkeeran. 2017. "Evaluation of Trichoderma spp. and Fungicides in the Management of Collar Rot of Gerbera Incited by Sclerotium rolfsii." Journal of Pure and Applied Microbiology 11 (2): 1161-1168.

Suryawanshi, A., A. Borgaonkar, D. Kuldhar, and U. Dey. 2015. "Integrated management of collar rot (Sclerotium rolfsii) of brinjal (Solanum melongena)." Indian Phytopath 68: 189-195.

Virupaksha Prabhu, H., P. Hiremath, and M. Patil. 1997. "Biological control of collar rot of cotton caused by Sclerotium rolfsii Sacc." Karnataka Journal of Agricultural Sciences 10:397-403.

Zarani, F., and C. Christias. 1997. "Sclerotial biogenesis in the basidiomycete Sclerotium rolfsii. A scanning electron microscope study." Mycologia 89 (4): 598-602.

\section{How to cite this article:}

Abinaya, A., K. Kalpana, E. G. Ebenezar, S. Thiruvudainambi, M. Theradimani and Arunkumar, R. 2020. Evaluation of Antagonistic Potential of Bacillus spp. and Trichoderma spp. against Sclerotium rolfsii Sacc. causing Collar Rot Disease in Solanum melongena L.. Int.J.Curr.Microbiol.App.Sci. 9(12): 694-703. doi: https://doi.org/10.20546/ijcmas.2020.912.083 